\title{
Frugivory by birds on Miconia albicans (MELASTOMATACEAE), in a fragment of cerrado in São Carlos, southeastern Brazil
}

\author{
Allenspach, $N$ * and Dias, MM. \\ Departamento de Ecologia e Biologia Evolutiva - DEBE, Universidade Federal de São Carlos - UFSCar, \\ Rod. Washington Luiz, Km 235, CP 676, CEP 13565-905, São Carlos, SP, Brazil \\ *e-mail: naty_allenspach@yahoo.com.br
}

Received May 11, 2011 - Accepted July 18, 2011 - Distributed May 31, 2012

(With 3 figures)

\begin{abstract}
The avian guild that consumes Miconia albicans (Melastomataceae) fruits and its phenophases were studied in a fragment of cerrado vegetation located in southeastern Brazil. The fruiting period ocurred between October and January, coinciding with the wet season. Nineteen bird species, mainly of generalistic diets, were registered consuming fruits in 96 observational hours. Species of the families Emberizidae, Thraupidae and Tyrannidae showed the largest number of visits, while those of the families Mimidae and Columbidae, with higher body mass, were responsible for a considerable number of consumed fruits. A correlation was found between body mass and average fruit consumption per visit. Tree height was a relevant factor for bird attraction. Results suggest that $M$. albicans may be useful in the recovery of degraded areas.
\end{abstract}

Keywords: frugivory, ornitochory, phenology, Miconia, cerrado.

\section{Frugivoria por aves em Miconia albicans (MELASTOMATACEAE), em um fragmento de cerrado em São Carlos, sudeste do Brasil}

\section{Resumo}

Foi estudada a guilda de aves que consomem frutos de Miconia albicans (Melastomataceae), bem como a fenologia dessa planta, em fragmento de cerrado no sudeste do Brasil. O período de frutificação ocorreu entre outubro e janeiro, coincidindo com a estação chuvosa. Dezenove espécies de aves, a maioria com dieta generalista, foram registradas consumindo frutos em 96 horas de observações. Espécies das famílias Emberizidae, Thraupidae e Tyrannidae apresentaram o maior número de visitas, enquanto aquelas das famílias Mimidae e Columbidae, de maior massa corporal, sobressaíram-se pelo número de frutos consumidos. Foi encontrada correlação entre massa corporal e consumo médio de frutos por visita. A altura das árvores foi um fator relevante na atração de aves. Os resultados sugerem que M. albicans pode ser útil na recuperação de áreas degradadas.

Palavras-chave: frugivoria, ornitocoria, fenologia, Miconia, cerrado.

\section{Introduction}

Cerrado is the major tropical savana area in South America (Ratter et al., 1997). This vegetation has been greatly reduced by anthropic action, with only several fragments of cerrado remaining in São Paulo state, usually of less than 100 ha each (São Paulo, 1997). Studies have demonstrated that aproximately $50 \%$ of cerrado woody species show zoochoric dispersal syndrome (Vieira et al., 2002; Neri et al., 2005). Birds and mammals are believed to be the most important seed dispersers (Howe and Westley, 1997).

Fruit-eating birds may be classified as specialised and opportunistic (Howe and Estabrook, 1977). Following this theory, plants whose dispersal agents are specialised birds would produce large fruits of high nutritional quality (elevated protein content), in a small number, but with

large seeds. On the other hand, plants that are dispersed mainly by opportunistic birds would produce small fruits with low nutritional quality (high carbohydrates and water levels), in a large number but with small seeds. Specialised and generalised dispersal systems constitute a paradigm (Howe, 1993) that still motivates research on frugivory and seed dispersal (Jordano et al., 2011).

According to Snow (1981), plants adapted for dispersal by opportunistic frugivorous birds are generally shrubs or small trees, typical from secondary vegetation, colonising edge habitats or recently cleared ground. The family Melastomataceae is an important example of these plants. Species of the genus Miconia represent approximately one quarter of the modern Melastomataceae, occuring from the 
south of Mexico to the north of Argentina and Uruguay (Goldenberg, 2004).

Miconia albicans (Triana) is a treelet that reaches even $3 \mathrm{~m}$ in height, occurring in cerrado secondary vegetation, rocky outcrops and coastal formations (Goldenberg, 2004). Its fruits are small and numerous rosy berries that become jade-green during ripening, with high levels of water and carbohydrates (respectively 76.63 and $13.38 \%$ ) but low protein content $(2.17 \%$ ) (Maruyama et al., 2007). Neri et al. (2005) observed high density of $M$. albicans occuring in regenerating cerrado areas.

Ecological aspects involved in bird-plant relationships have been used in environmental risk assessments and to create biodiversity conservation arrangements, so as to estimate future impoverishment and reduction of original vegetation (Howe and Miriti, 2000; Silva and Tabarelli, 2000). The present study aimed to characterize the avian guild that consumes fruits of Miconia albicans and the phenology of the plant, in an attempt to better understand the ecological role of this plant in the fragment studied.

\section{Material and Methods}

The study was carried out in a non urbanised area in the campus of the Universidade Federal de São Carlos, São Paulo state, southeastern Brazil ( $21^{\circ} 58^{\prime} \mathrm{S}$ and $\left.47^{\circ} 52^{\prime} \mathrm{W}\right)$. This is a 124.68 ha area (Paese, 1997) where cerrado vegetation is very compromised by irregular fires and by Brachiaria sp. and Melinis sp. (Poaceae) invasion. The regional climate is Cwa.i - Awi (Köppen's system); with wet summers and dry winters (Tolentino, 2007).

According to Dias, Branco and Francisco (in press), a total of 274 bird species have already been sighted in the campus area, and $33 \%$ are believed to consume fruits, at least sporadically (Francisco and Galetti, 2001). In research performed with woody species in the area, M. albicans appears as the fourth most abundant species (Oliveira and Batalha, 2005).
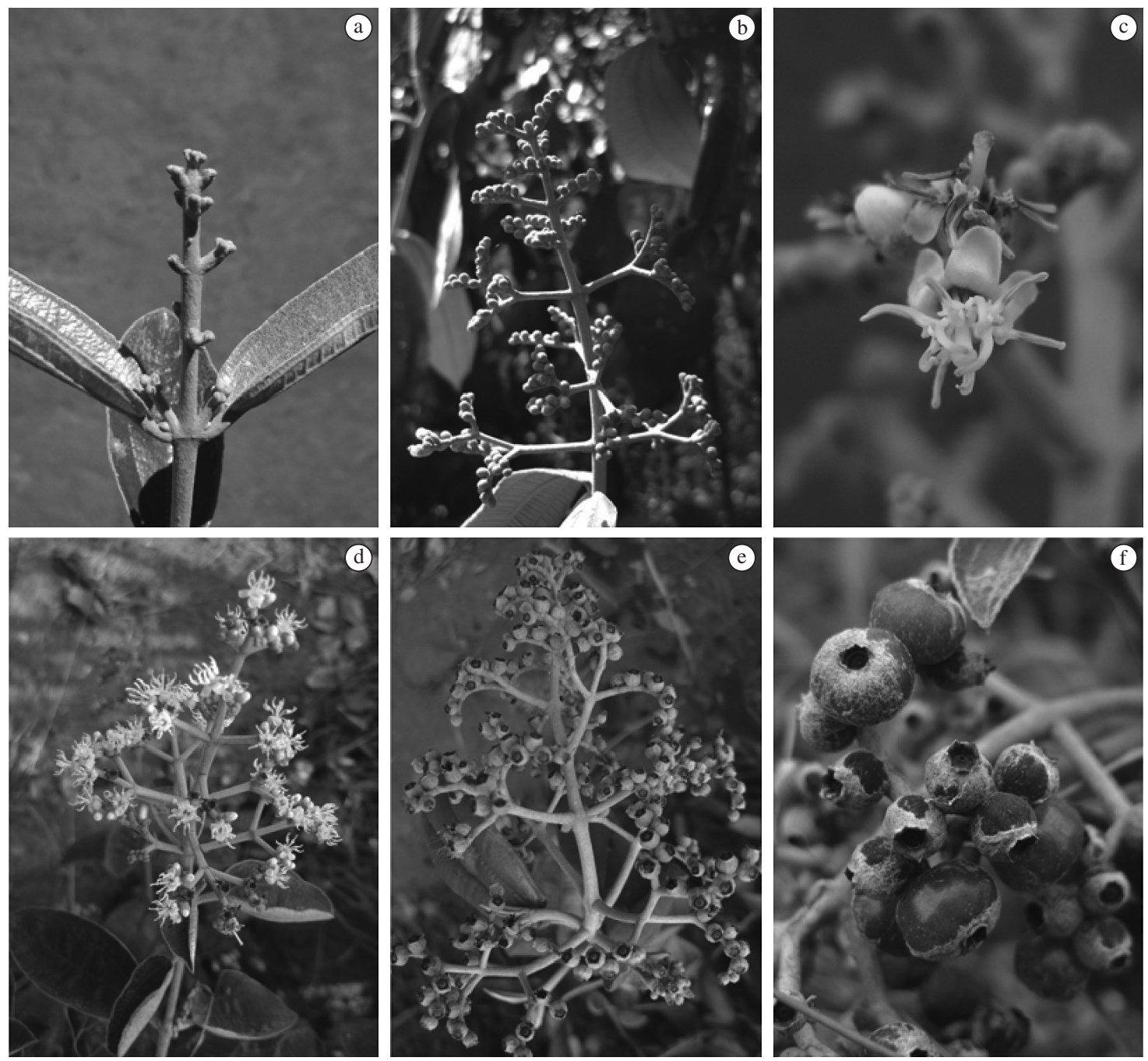

Figure 1. Miconia albicans phenophases. a,b) flower buds, c) flower, d) inflorescence, e) immature fruits, f) immature and ripe fruits. 
Miconia albicans phenophases (Figure 1) were accompanied every two weeks, between March 2008 and February 2009, following 30 random selected individuals in a pre-existing $800 \mathrm{~m}$ trail. Since each treelet has a huge number of flower buds, flowers and/or fruits, it was necessary to estimate the total from an average of direct counting on three inflorescences per individual. Field data was analysed using the Fournier intensity percentage (Fournier, 1974), in a classificatory scale from 0 (phenophase absent) to 4 (maximum phenophase intensity). The activity index (percentage of individuals that show the phenophase) per month was also estimated, since both methodologies supply complementary data (Bencke and Morellato, 2002).

The survey of birds consuming M. albicans fruits was carried out using the focal tree methodology (Pizo, 1997) between November and December 2008, when a fruiting peak was registered. Eight treelets were observed from a minimum distance of $8-10 \mathrm{~m}$, with $7 \times 35$ binoculars, trying in this way to avoid behavioural changes by the visitants. The following aspects were registered: visiting species, time and duration of the visit, number of consumed fruits, foraging behaviour, occurence of agonistic encounters and occurrence of defecation and regurgitation. Each treelet
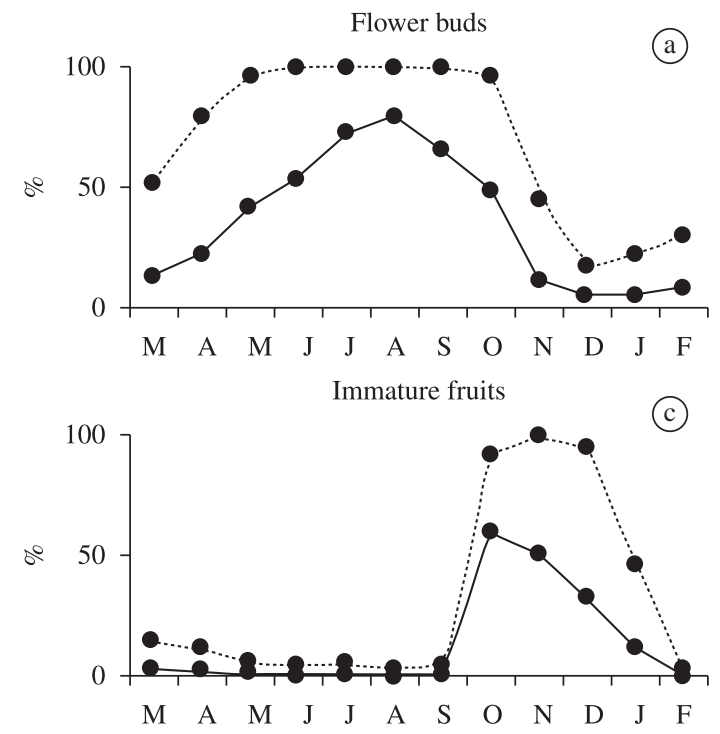

(e)

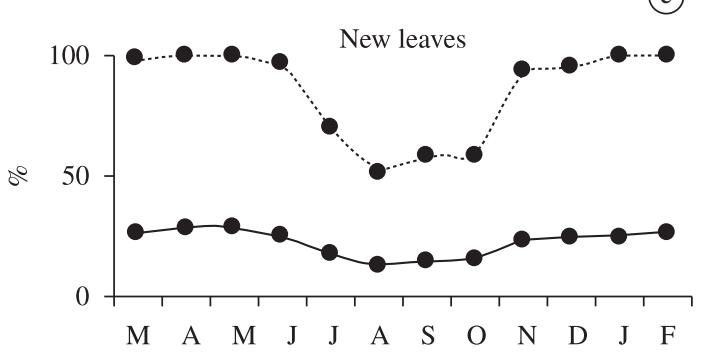

Activity index was observed for 12 hours, alternating non-consecutive days, totalling 96 observational hours. However, the observations were equally distributed over the day, from 6:00 AM to 6:00 PM, so each time interval was equally sampled in every plant.

Miconia albicans has a very dense crown, which made visualization difficult. So, in order to calculate averages and frequencies for bird visits, only those with recorded duration and fruit consumption were considered. For some species, the total number of visits used to calculate average consumption of fruits per visit is not the same utilised in the calculation of average visit duration.

For correlational analyses, the Spearman correlation coefficient was applied. Body masses and predominant diets were obtained from the literature (Motta-Junior, 1990; Marini et al., 1997; Sick, 1997; Piratelli and Pereira, 2002; Antunes, 2005). Meteorological data is available at Embrapa (2009).

\section{Results}

Flowering occured between August and October (Figure 2), when an activity peak was observed. September
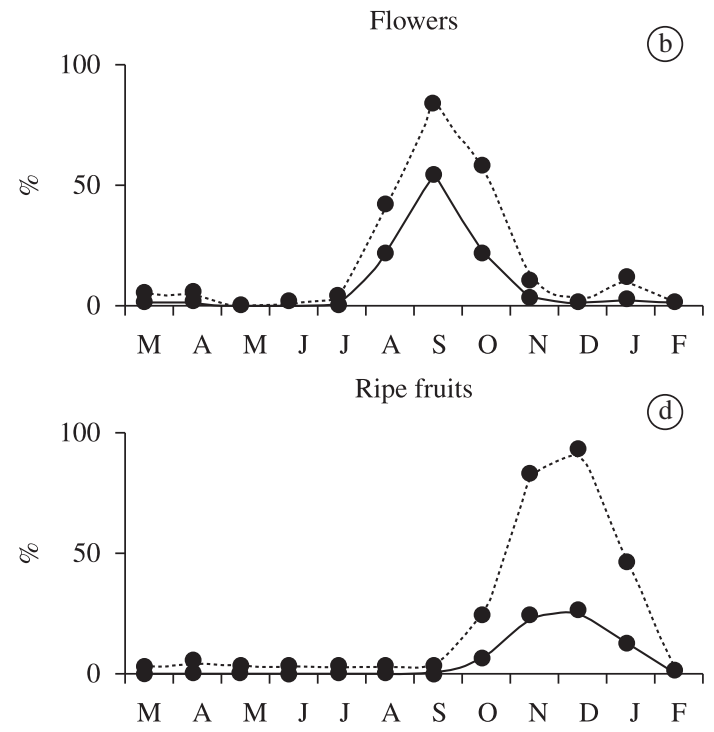

(f)

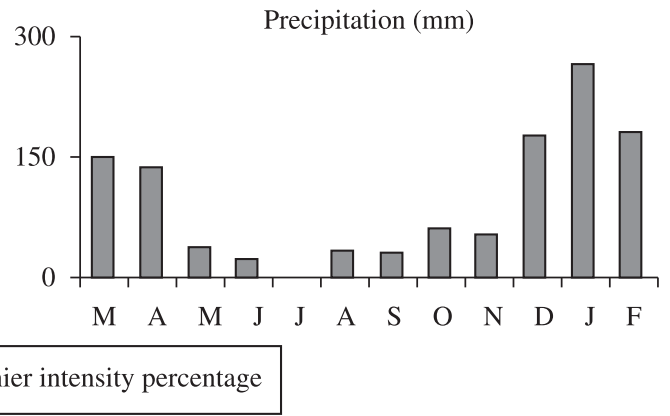

Figure 2. Activity index and Fournier intensity percentage of the phenophases observed in 30 adult trees of Miconia albicans, between March 2008 and February 2009. Months are represented by their capital letters. a) Flower buds, b) Flowers, c) Immature fruits, d) Ripe fruits, e) New leaves, f) Precipitation (mm). 
Table 1. Bird species recorded consuming Miconia albicans fruits during 96 observational hours. a) Number of observations with complete data of visit duration. b) Number of observations with complete data of fruit consumption. c) Total consumed fruits per species. d) Main diet, according Motta-Junior (1990); Piratelli and Pereira (2002): FRU = frugivore; INS = insectivore; $\mathrm{ONI}=$ omnivore; $\mathrm{SE}=$ seed eaters.

\begin{tabular}{|c|c|c|c|c|c|c|c|}
\hline Species & Visits & $\begin{array}{l}\mathbf{N} \\
\text { (a) }\end{array}$ & $\begin{array}{l}\text { Average } \\
\text { visit duration } \\
\text { (seconds) }\end{array}$ & $\begin{array}{l}\mathbf{N} \\
(\mathbf{b})\end{array}$ & $\begin{array}{l}\text { Consumed } \\
\text { fruits } \\
\text { (c) }\end{array}$ & $\begin{array}{l}\text { Average } \\
\text { fruit } \\
\text { consumed }\end{array}$ & $\begin{array}{l}\text { Diet } \\
\text { (d) }\end{array}$ \\
\hline \multicolumn{8}{|l|}{ Columbidae } \\
\hline Patagioenas picazuro (Temminck) & 24 & 11 & $410.64 \pm 222.48$ & 7 & 232 & $33.14 \pm 24.28$ & FRU \\
\hline \multicolumn{8}{|l|}{ Psittacidae } \\
\hline Aratinga aurea (Gmelin) & 2 & 0 & - & 1 & 24 & $24.00 \pm 0.00$ & FRU \\
\hline \multicolumn{8}{|l|}{ Tyrannidae } \\
\hline Elaenia sp. & 3 & 3 & $31.00 \pm 13.45$ & 3 & 9 & $3.00 \pm 2.65$ & ONI \\
\hline Myiarchus sp. & 1 & 1 & $18.00 \pm 0.00$ & 1 & 3 & $3.00 \pm 0.00$ & \\
\hline $\begin{array}{l}\text { Myiodynastes maculatus } \\
\text { (Statius Muller) }\end{array}$ & 8 & 8 & $81.25 \pm 62.75$ & 8 & 46 & $5.75 \pm 5.37$ & ONI \\
\hline Pitangus sulphuratus (Linnaeus) & 9 & 9 & $136.22 \pm 201.36$ & 7 & 27 & $3.86 \pm 4.06$ & ONI \\
\hline Tyrannus albogularis Burmeister & 1 & 1 & $74.00 \pm 0.00$ & 1 & 8 & $8.00 \pm 0.00$ & INS \\
\hline Tyrannus melancholicus Vieillot & 1 & 1 & $151.00 \pm 0.00$ & 1 & 13 & $13.00 \pm 0.00$ & INS \\
\hline Tyrannus savana Vieillot & 16 & 15 & $59.53 \pm 35.55$ & 13 & 79 & $6.08 \pm 3.84$ & INS \\
\hline \multicolumn{8}{|l|}{ Corvidae } \\
\hline Cyanocorax cristatellus (Temminck) & 3 & 0 & - & 0 & - & - & ONI \\
\hline \multicolumn{8}{|l|}{ Turdidae } \\
\hline Turdus leucomelas (Vieillot) & 9 & 6 & $107.67 \pm 139.08$ & 7 & 79 & $11.29 \pm 6.42$ & ONI \\
\hline \multicolumn{8}{|l|}{ Mimidae } \\
\hline Mimus saturninus (Lichtenstein) & 19 & 14 & $127.21 \pm 95.28$ & 13 & 281 & $21.62 \pm 24.09$ & INS \\
\hline \multicolumn{8}{|l|}{ Thraupidae } \\
\hline Saltatricula atricollis Vieillot & 1 & 1 & $49.00 \pm 0.00$ & 1 & 7 & $7.00 \pm 0.00$ & SE \\
\hline Schistochlamys ruficapillus (Vieillot) & 2 & 2 & $67.50 \pm 61.52$ & 2 & 3 & $1.50 \pm 2.12$ & ONI \\
\hline Tangara cayana (Linnaeus) & 6 & 6 & $74.33 \pm 98.21$ & 3 & 35 & $11.67 \pm 11.55$ & ONI \\
\hline Tangara sayaca (Linnaeus) & 33 & 17 & $102.94 \pm 71.38$ & 12 & 161 & $13.42 \pm 9.18$ & ONI \\
\hline \multicolumn{8}{|l|}{ Emberizidae } \\
\hline Sporophila caerulescens (Vieillot) & 34 & 21 & $108.52 \pm 130.98$ & 20 & 100 & $5.00 \pm 4.41$ & SE \\
\hline Volatinia jacarina (Linnaeus) & 19 & 11 & $143.36 \pm 73.97$ & 8 & 37 & $4.63 \pm 3.02$ & SE \\
\hline Zonotrichia capensis (Statius Muller) & 21 & 20 & $98.85 \pm 57.83$ & 12 & 60 & $5.00 \pm 3.64$ & SE \\
\hline Total & 212 & 147 & - & 120 & 1204 & - & - \\
\hline
\end{tabular}

was the only month when flower intensity went over $50 \%$. However, it is important to emphasize the fact that the number of flowers registered is lower than the real number, since they keep open for a few days only, and so could not all be registered on the biweekly surveys. The procedure also explains the mismatching between the low number of flowers in relation to the large number of immature fruits recorded afterwards.

A peak in the activity index and in the Fournier intensity percentage of ripe fruits was observed between October and January. This interval was considered the fruiting period of $M$. albicans and coincided with the wet season. Morphometric data of the fruits $(n=50)$ were: diameter $6.3( \pm 0.587) \mathrm{mm}$ and average weight of $0.14( \pm 0.034) \mathrm{g}$. A mean of $19.52( \pm 6.34)$ seeds per fruit was found, with average weight of $7.047 \mathrm{mg}$ each $(\mathrm{n}=1000)$. Seeds correspond to approximately $5.06 \%$ of the fruit weight.

Only birds were observed consuming $M$. albicans fruits. A total of 212 visits with fruit consumption were registered, performed by 19 bird species, from eight families (Table 1). Any new species was observed consuming M. albicans fruits after 72 hours of observation. An average frequency of $2.21 \pm 3.48$ visits/hour was found, with a peak of $5.4 \pm 6.0$ visits/hour registered between 6:00 AM and 7:00 AM. During the day, the frequency of visits decreased, until its minimum value $(0.3 \pm 0.5)$ between 5:00 PM and 6:00 PM.

Species of the family Emberizidae were the most representative in number of visits $(34.9 \%)$, followed by Thraupidae (19.81\%) and Tyrannidae (18.4\%) families. In relation to fruit consumption, species of the families Mimidae, 
Columbidae and Thraupidae were the most responsible, with $23.34,19.27$ and $17.11 \%$ respectively of consumption. Many birds with juvenile plumage were observed consuming M. albicans fruits, notably Sporophila caerulescens, Volatinia jacarina and Mimus saturninus.

Although species of family Emberizidae - which has a typical grain diet (Sick, 1997) - had a prominent number of visits, they were seen in the majority of the visits taking the seeds out of the fruits and rejecting pulp and skin. Sporophila caerulescens, Volatinia jacarina and Zonotrichia capensis have already been registered in the same area as granivores (Motta-Junior, 1990) and since mainly seeds are found fragmented in Emberizidae's stomach (Lopes et al., 2005) they are believed not to be great seed dispersers. Aratinga aurea (Figure 3), Tangara cayana and Saltatricula atricollis were observed mandibulating fruits, but degluting them totally. This behaviour may destroy seeds or not (Moermond, 1983) and only germination tests can verify if these species might act as $M$. albicans seed dispersers.

Regurgitation, defecation and agonistic encounters were insignificant for all species observed. The average fruit consumption per visit varied from 1.5 fruit/visit (Schistochlamys ruficapillus) to 33.14 (Patagioenas picazuro). A correlation was found between body mass and average fruit consumption per visit (Spearman correlation coeficient: $\mathrm{rs}=0.549 ; \mathrm{p}=0.023$ ) but no significant correlation between average fruit consumption per visit and average visit duration.

Miconia albicans treelets used for focal observations varied from 1.5 to $3.0 \mathrm{~m}$, and hold between 600 and 9000 available fruits (ripe and immature). There is a correlation between tree height and number of visits (Spearman correlation coeficient: $r s=0.753 ; p=0.031$ ), but no significant correlation was found between the available fruits and number of visits.

During the survey, the predation of a Tangara sayaca that was consuming M. albicans fruits, by a Callithrix jaccus (Linnaeus) (Cebidae) was observed. At 6:45 AM, three adult marmosets came to a $M$. albicans treelet and kept inside

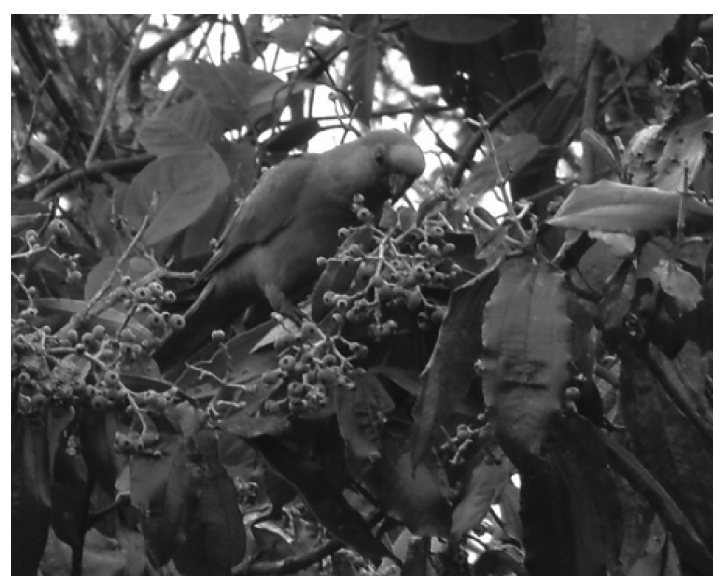

Figure 3. Aratinga aurea feeding on Miconia albicans fruits. its crown, that was dense and so hampered visualization. This treelet was being visited by many $T$. sayaca at that moment. A few minutes later, one marmoset left the plant with the already dead bird in its claws, went to a higher neighbouring tree (about $5 \mathrm{~m}$ high) and fed on the bird. The other two marmosets followed the first, but they kept a distance from each other. Then, the group came back to the $M$. albicans treelet (bringing the bird carcass together), stayed for a few minutes and left.

\section{Discussion}

Miconia albicans treelets showed a high syncrony, with remarkable phenophases. Synchronised fruit production may be a strategy to increase the attractiveness of the frugivorous species responsible for seed dispersal (Augspurger, 1981). The fruiting period coincides with the wet season, when many fruits of other ornithocoric dispersion syndrome plants are available in the same area, like: Davila rugosa Poiret (Dilleniaceae) (Francisco and Galetti, 2002a), Ocotea pulchella (Nees) Mez (Lauraceae) (Francisco and Galetti, 2002b), Pera glabrata (Schott) Baill (Euphorbiaceae) (Francisco et al., 2007), Rapanea lancifolia (Ruiz and Pavon) Mez (Francisco and Galetti, 2001) and Zanthoxylum rhoifolium Lam. (Rutaceae) (Silva et al., 2008).

Fruit richness in the period and the high abundance of $M$. albicans in the studied area (Oliveira and Batalha, 2005) may be an explanation for the low frequency of visits observed for M. albicans. In comparison to data from the abovementioned literature, $M$. albicans showed from similar to a 3 times lower frequency of bird visits, while the number of observed species could be considered high (in a range of 11 species for $R$. lancifolia to 20 for P. glabrata). However, since there are annual climate variations and different methodologies applied, comparisons must be regarded with caution.

Fruit abundance during $M$. albicans fruiting season could explain either the absent correlation between available fruits per treelet and number of visits, since M. albicans fruits are of low nutritional quality. These fruits are eaten mainly by birds with generalist diets which seek better protein sources. Only treelet height showed to be a relevant factor for bird attraction. Since safety is not completely associated with perching height (Blumstein et al., 2004), it is the interaction with many other factors that results in the tree choice by the birds: forraging patterns, plant community composition and structure, predation risk (Howe, 1979; Robinson and Holmes, 1982; Levey and Moermond, 1984; Hasuí et al., 2007).

Large and cryptic birds are less vulnerable to predators, spending more time on fruiting plants (Pratt and Stiles, 1983; Silva et al., 2008). The heaviest bird observed consuming $M$. albicans fruits, $P$. picazuro, showed the largest average visit duration $(410,64 \pm 222,48$ seconds). The marmoset predation of a small bird consuming M. albicans fruits is a strong example of the importance of predation risk during bird feed. The lack of a correlation between average fruit consumption per visit and average visit duration may be 
a consequence of variated time spent in state of allertness during the visit, just as of different foraging patterns used by each species or previous consumption of other food sources.

Miconia albicans seed dispersal potential by birds could only be inferred through the behavioural aspects observed in the survey. Short visits (less than 3 minutes) and low defecation rates means that seeds may be carried out far away from the parent-plant (Pratt and Stiles, 1983). Future studies are necessary to verify the dispersive potential of the birds here listed and also know M. albicans germination and seedling characteristics.

Characterised by a generalist dispersal system, M. albicans seeds may be dispersed even in disturbed areas where large frugivores are absent. As a pioneer plant, it is known that M. albicans is able to naturally establish under Eucalyptus sp. plantations (Saporetti et al., 2003). All these attributes suggest $M$. albicans may be useful in the recovery of degraded areas.

Ackonowledgements - Thanks to Dra. Maria Inês Salgueiro Lima for Melastomataceae identification, and to the biologist Julia Ramos Estêvão for helping during field studies. N. Allenspach received a Master's scholarship from CAPES.

\section{References}

ANTUNES, AZ., 2005. Alteração na composição da comunidade de aves ao longo do tempo em um fragmento florestal no sudeste do Brasil. Ararajuba, vol. 13, no. 1, p. 47-61.

AUGSPURGER, CK., 1981. Reproductive synchrony of a tropical shrub: experimental studies of effects of pollinators and seed predators in Hybanthus prunifolius (Violaceae). Ecology, vol. 62, no. 3, p. 775-788. http://dx.doi.org/10.2307/1937745

BENCKE, CSC. and MORELLATO, LPC., 2002. Comparação de dois métodos de avaliação da fenologia de plantas, sua interpretação e representação. Revista Brasileira de Botânica, vol. 25 , no. 3 , p. $269-274$.

BLUMSTEIN, DT., FERNÁNDEZ-JURICIC, E., LEDEE, O., LARSEN, E., RODRIGUEZ-PRIETO, I. and ZUGMEYER, C., 2004. Avian risk assessment: effects of perching height and detectability. Ethology, vol. 110, p. 273-285.

DIAS, MM., BRANCO, MBC. and FRANCISCO, MR., In press. A avifauna da UFSCar, Campus São Carlos, Estado de São Paulo: 34 anos de levantamentos. In LIMA, MIS. and PENTEADO-DIAS, MA. Ambientes terrestres do Campus da UFSCar, São Carlos, Estado de São Paulo.

EMBRAPA. Pecuária Sudeste, 2009. Serviços - dados meteorológicos. Available from: <http://www.cppse.embrapa.br>. Access in: 10 mar. 2009.

FRANCISCO, MR. and GALETTI, M., 2001. Frugivoria e dispersão de sementes de Rapanea lancifolia (Myrcinaceae) por aves numa área de cerrado do Estado de São Paulo, Sudeste do Brasil. Ararajuba, vol. 9, no. 1, p. 13-19.

-, 2002a. Consumo dos frutos de Davilla rugosa (Dilleniaceae) por aves numa área de cerrado em São Carlos, Estado de São Paulo. Ararajuba, vol. 10, no. 2, p. 193-198.
-, 2002b. Aves como potenciais dispersoras de sementes de Ocotea pulchella Mart. (Lauraceae) numa área de vegetação de cerrado do sudeste brasileiro. Revista Brasileira de Botânica, vol. 25, no. 1, p. 11-17.

FRANCISCO, MR., LUNARDI, VO. and GALETTI, M., 2007. Bird attributes, plants characteristics, and seed dispersal of Pera glabrata (Schott, 1858), (Euphorbiaceae) in a disturberd cerrado area. Brazilian Journal of Biology, vol. 67, no. 4, p. 627-634.

FOURNIER, LA., 1974. Un método cuantitativo para la medición de características fenológicas en arboles. Turrialba, vol. 24, no. 4 , p. 422-423.

GOLDENBERG, R., 2004. O gênero Miconia (Melastomataceae) no Estado do Paraná, Brasil. Acta Botanica Brasilica, vol. 18, no. 4, p. 927-947. http://dx.doi.org/10.1590/S0102-33062004000400024

HASUÍ, E., MOTA GOMES, VS. and SILVA, WR., 2007. Effects of vegetation traits on habitat preferences of frugivorous birds in atlantic rain forest. Biotropica, vol. 39, no. 4, p. 502-509. http:// dx.doi.org/10.1111/j.1744-7429.2007.00299.x

HOWE, HF., 1979. Fear and frugivory. American Naturalist, vol. 114, no. 6, p. 925-931. http://dx.doi.org/10.1086/283540

-, 1993. Specialized and generalized dispersal systems: where does ‘the paradigm' stand? Vegetatio, vol. 107-108, p. 3-13.

HOWE, HF. and ESTABROOK, G., 1977. On intraspecific competition for avian dispersers in tropical trees. American Naturalist, vol. 111, p. 817-832. http://dx.doi.org/10.1086/283216

HOWE, HF. and MIRITI, MN., 2000. No question: seed dispersal matters. Tree, vol. 11, no. 15, p. 434-436.

HOWE, HF. and WESTLEY, L., 1997. Ecology of pollination and seed dispersal. In CRAWLEY, MJ. (Ed.). Plant Ecology. 2nd. ed. London: Blackwell Science. p. 262-283.

JORDANO, P., FORGET, PM., LAMBERT, JE., BÖHNING-GAESE, K., TRAVESET, A., WRIGHT, SJ., 2011. Frugivores and seed dispersal: mechanisms and consequences for biodiversity of a key ecological interaction. Biology Letters, vol. 7, p. 321-323. PMid:21084336. http://dx.doi.org/10.1098/rsbl.2010.0986

LEVEY, DJ. and MOERMOND, TC., 1984. Fruit choice in neotropical birds: the effect of distance between fruits on preference patterns. Ecology, vol. 65, no. 3, p. 844-850. http://dx.doi. org/10.2307/1938058

LOPES, LE., FERNANDES, AM. and MARINI, MA., 2005. Diet of some Atlantic Forest birds. Ararajuba, vol. 13, no. 1, p. 95-103.

MARINI, MA., MOTTA-JÚNIOR, JC., VASCONCELLOS, LAS. and CAVALCANTI, RB., 1997. Avian body masses from the cerrado region of central Brazil. Ornitologia Neotropical, vol. 8, p. 93-99.

MARUYAMA, PK., ALVES-SILVA, E. and MELO, C., 2007. Oferta qualitativa e quantitativa de frutos em espécies ornitocóricas do gênero Miconia (Melastomataceae). Revista Brasileira de Biociências, vol. 5, no. 1, p. 672-674.

MOERMOND, TC., 1983. Suction-drinking in tanagers and its relation to fruits handling. Ibis, vol. 125, p. 545-549.

MOTTA-JUNIOR, JC., 1990. Estrutura trófica e composição das avifaunas de três hábitats terrestres na região central do estado de São Paulo. Ararajuba, vol. 1, p. 65-71.

NERI, AV., CAMPOS, EP., DUARTE, TG., MEIRA NETO, JAA., FRANCISCO DA SILVA, A. and VALENTE, GE., 2005. 
Regeneração de espécies nativas lenhosas sob plantio de Eucalyptus em área de cerrado na Floresta Nacional de Paraopeba, MG, Brasil. Acta Botanica Brasilica, vol. 19, no. 2, p. 369-376. http://dx.doi. org/10.1590/S0102-33062005000200020

OLIVEIRA, FF. and BATALHA, MA., 2005. Lognormal abundance distribution of woody species in a cerrado fragment (São Carlos, Southeasthern Brazil). Revista Brasileira de Botânica, vol. 28, no. 1, p. 39-45.

PAESE, A., 1997. Caracterização e análise ambiental do campus da Universidade Federal de São Carlos (UFSCar), São Carlos, Brasil. São Carlos: Universidade Federal de São Carlos. Dissertação de Mestrado em Ecologia.

PIRATELLI, A. and PEREIRA, MR., 2002. Dieta de aves na região leste do Mato Grosso do Sul, Brasil. Ararajuba, vol. 10, no. 2, p. 131-139.

PIZO, MA., 1997. Seed dispersal and predation in two populations of Cabralea canjerana (Meliaceae) in the Atlantic Forest of southeastern Brazil. Journal of Tropical Ecology, vol. 13, p. 559-578. http://dx.doi.org/10.1017/S0266467400010713

PRATT, TK. and STILES, EW., 1983. How long fruit-eating birds stay in the plants where they feed: implications for seed dispersal. American Naturalist, vol. 122, no. 6, p. 797-805. http:// dx.doi.org/10.1086/284172

RATTER, JA., RIBEIRO, JF. and BRIDGEWATER, S., 1997. The Brazilian cerrado vegetation and threats to its biodiverisity. Annals of Botany, vol. 80, p. 223-230. http://dx.doi.org/10.1006/ anbo.1997.0469

ROBINSON, SK. and HOLMES, RT., 1982. Foraging behavior of forest birds: the relationships among search tactics, diet, and habitat structure. Ecology, vol. 63, no. 3, p. 1918-1931.
São Paulo (Estado). Secretaria de Estado do Meio Ambiente - SMA,1997. Cerrado: bases para conservação e uso sustentável das áreas de cerrado do estado de São Paulo. São Paulo. 113 p.

SAPORETTI JUNIOR, AW., MEIRA NETO, JAL., ALMADO, R., 2002. Fitossociologia de sub-bosque de cerrado em talhão de Eucalyptus grandis W. Hill ex Maiden no município de Bom Despacho/MG. Revista Árvore, vol. 27, no. 6, p. 905-910.

SICK, H., 1997. Ornitologia brasileira. Rio de Janeiro: Nova Fronteira. 912 p.

SILVA, IA., FIGUEIREDO, RA. and MATOS, DMS., 2008. Feeding visit time of fruit-eating birds in cerrado plants: revisiting the predation risk model. Brazilian Journal of Biology, vol. 25, no. 4 , p. $682-688$.

SILVA, JMC. and TABARELLI, M., 2000. Trees species impoverishment and the future flora of the Atlantic flora of Northeast Brazil. Nature, vol. 404, p. 72-74. PMid:10716443. http://dx.doi.org/10.1038/35003563

SNOW, DW., 1981. Tropical frugivorous birds and their food plants: a world survey. Biotropica, vol. 13, no. 1, p. 1-14. http:// dx.doi.org/10.2307/2387865

TOLENTINO, M., 2007. Estudo crítico sobre o clima da região de São Carlos. São Carlos: EdUFSCar. 78 p.

VIEIRA, DLM., AQUINO, FG.; BRITO, MA.; FERNANDES-BULHÃO, C. and HENRIQUES, RPB., 2002. Síndromes de dispersão de espécies arbustivo-arbóreas em cerrado sensu stricto do Brasil Central e savanas amazônicas. Revista Brasileira de Botânica, vol. 25, no. 2, p. 215-220. 
